\title{
Defining the optimal period length and stage of growth or lactation to estimate residual feed intake in dairy cows
}

\author{
E. E. Connor, ${ }^{*}$ J. L. Hutchison, C. P. Van Tassell, and J. B. Cole \\ Animal Genomics and Improvement Laboratory, USDA, Agricultural Research Service, Beltsville, MD 20705
}

\section{ABSTRACT}

Residual feed intake (RFI) is an estimate of animal feed efficiency, calculated as the difference between observed and expected feed intake. Expected intake typically is derived from a multiple regression model of dry matter intake on energy sinks, including maintenance and growth in growing animals, or maintenance, gain in body reserves, and milk production in lactating animals. The best period during the production cycle of a dairy cow to estimate RFI is not clear. Here, we characterized RFI in growing Holstein heifers $\left(\mathrm{RFI}_{\text {Growth }} \sim 10\right.$ to 14 mo of age; $\mathrm{n}=226$ ) and cows throughout a 305 -d lactation $\left(\mathrm{RFI}_{\mathrm{Lac}-\mathrm{Full}} ; \mathrm{n}=118\right)$. The goals were to characterize relationships between RFI estimated at different production stages of the dairy cow; determine effects of selection for efficiency during growth on subsequent lactation and feed efficiency; and identify the most desirable testing scheme for $\mathrm{RFI}_{\mathrm{Lac}-F u l l}$. For $\mathrm{RFI}_{\text {Growth }}$, intake was predicted from multiple linear regression of metabolizable energy (ME) intake on mid-test body weight $(B W)^{0.75}$ and average daily gain (ADG). For $\mathrm{RFI}_{\mathrm{Lac}-\mathrm{Full}}$, predicted intake was based on regression of $\mathrm{BW}^{0.75}, \mathrm{ADG}$, and energy-corrected milk yield. Mean energy intake of the least and most efficient growing heifers $\left( \pm 0.5\right.$ standard deviations from mean $\mathrm{RFI}_{\text {Growth }}$ of 0) differed by 3.01 Mcal of $\mathrm{ME} / \mathrm{d}$, but the groups showed no difference in mid-test BW or ADG. Phenotypic correlation between $\mathrm{RFI}_{\text {Growth }}$ and RFI of heifers estimated in the first $100 \mathrm{~d}$ in milk $\left(\mathrm{RFI}_{\mathrm{Lac100DIM}} ; \mathrm{n}=\right.$ 130) was 0.37. Ranking of these heifers as least (mean +0.5 standard deviations), middle, or most efficient (mean - 0.5 standard deviations) based on $\mathrm{RFI}_{\text {Growth }}$ resulted in $43 \%$ maintaining the same ranking by $\mathrm{RFI}_{\mathrm{Lac100DIM}}$. On average, the most efficient heifers ate 3.27 Mcal of ME/d less during the first 100 DIM than the least efficient heifers, but exhibited no differences in average energy-corrected milk yield, ADG, or BW. The correlation between $\mathrm{RFI}_{\text {Lac100DIM }}$ and $\mathrm{RFI}_{\text {Lac-Full }}$ was

Received July 18, 2018.

Accepted March 1, 2019.

*Corresponding author: erin.connor@ars.usda.gov
0.72. Thus, $\mathrm{RFI}_{\text {Growth }}$ may serve as an indicator trait for RFI during lactation, and selection for heifers exhibiting low $\mathrm{RFI}_{\text {Growth }}$ should improve overall herd feed efficiency during lactation. Correlation analysis between $\mathrm{RFI}_{\text {Lac-Full }}$ (10 to $305 \mathrm{DIM}$ ) and subperiod estimates of RFI during lactation indicated a test period of 64 to 70 $\mathrm{d}$ in duration occurring between 150 to 220 DIM provided a reliable approximation $(\mathrm{r} \geq 0.90)$ of $\mathrm{RFI}_{\text {Lac-Full }}$ among the test periods evaluated.

Key words: dairy cow, dairy heifer, feed efficiency, residual feed intake

\section{INTRODUCTION}

It is estimated that feed costs averaged $51 \%$ of dairy production costs in the United States between 2010 and 2017 (USDA ERS, 2018), making feed conversion efficiency a desirable target for genetic improvement. However, to make genetic progress, the trait must be heritable and selectable, and its evaluation in large numbers of individuals should be manageable and cost effective. Feed efficiency of dairy cattle has been estimated using residual feed intake (RFI), expressed as the difference between actual feed (or energy) intake of an individual and that expected based on its energy requirements (e.g., milk production, weight gain/loss, pregnancy, and maintenance; Connor, 2015). A positive RFI value means feed intake is greater than expected and indicates an inefficient animal, whereas a negative value means intake is less than expected and indicates a more efficient animal. Research on methods to estimate RFI, the biological basis of its variation, and its utility in genomic selection of dairy cattle continues to evolve since Koch et al. (1963) first introduced RFI as an estimate of metabolic efficiency of growing beef cattle (e.g., see reviews by Berry and Crowley, 2013; Pryce et al., 2014; Connor, 2015; Løvendahl et al., 2018). Implementation of genomic selection for improved (reduced) RFI in dairy cattle has been proposed (Gonzalez-Recio et al., 2014; Pryce et al., 2014; VandeHaar et al., 2016), although present accuracy of genomic breeding values is generally low $(\leq 0.4)$, in part due to limited availability of RFI phenotypes from genotyped individuals (Pryce et al., 2014). 
Beyond cost constraints associated with estimating RFI among livestock, estimation of RFI in lactating dairy cattle is particularly difficult due to vast fluctuations in the energy requirements of the cow throughout her lactation cycle. One study found that RFI estimates during different lactational stages [e.g., early ( $<57$ DIM) versus late lactation] are essentially different traits $(\mathrm{Li}$ et al., 2017). Weak phenotypic correlations $(\mathrm{r}=0.12$ to 0.23 ) between RFI estimates in early ( 8 to 90 DIM), mid (91 to 180 DIM), and late lactation (>180 DIM) were reported by Hurley et al. (2018) for grazed dairy cows. Likewise, correlations reported by Mäntysaari et al. (2012) were poor between RFI estimates made from approximately 14 to 77 DIM versus 78 to 147 DIM (r $=0.47)$ and 148 to 217 DIM $(r=0.40)$. We previously examined the minimum test duration to assess RFI in the first 90 DIM and found that sufficient data can be obtained from a test period through 53 DIM (Connor et al., 2013); however, test duration and optimal test period within lactation to best assess RFI during a complete (i.e., 305-d) lactation remain unknown. Furthermore, relationships between RFI estimated in growing dairy heifers $\left(\mathbf{R F I}_{\text {Growth }}\right)$ and RFI estimated during the first lactation have been examined in few studies to date (Davis et al., 2014; Macdonald et al., 2014), which suggested the potential use of $\mathrm{RFI}_{\text {Growth }}$ as a proxy for RFI during lactation.

This study aimed to characterize $\mathrm{RFI}_{\text {Growth }}$ in growing heifers and changes in RFI throughout a 305-d lactation, and determine phenotypic correlations between $\mathrm{RFI}_{\mathrm{Lac}-\mathrm{Full}}$ and estimates based on shorter windows of time within the lactation. This information will support development of more affordable and practical RFI testing schemes for lactating cows. Additionally, phenotypic correlations between $\mathrm{RFI}_{\text {Growth }}$ estimated in Holstein heifers between approximately 10 and 14 mo of age and $\mathrm{RFI}_{\text {Lac100DIM }}$ were examined to determine the utility of $\mathrm{RFI}_{\text {Growth }}$ as a substitute estimate, or predictor, of $\mathrm{RFI}_{\text {Lac100DIM. Finally, differences in lactation }}$ performance were evaluated in heifers phenotypically divergent in $\mathrm{RFI}_{\text {Growth }}$.

\section{MATERIALS AND METHODS}

All animal procedures were approved by the USDA Agricultural Research Service (ARS), Northeast Area Institutional Animal Care and Use Committee, protocol numbers 07-016, 10-013, 13-018, 16-004, and 17-017.

\section{Calculation of $R F_{L a c}$ During a 305-d Lactation}

Data for estimating $\mathrm{RFI}_{\text {Lac-Full }}$ were available from 118 registered Holstein cows $[\mathrm{n}=108$ first lactation; $\mathrm{n}=10$ multiparous (2 to 5 lactations)] from the USDA Belts- ville Agricultural Research Center (BARC) Dairy Herd (Beltsville, MD) collected between September 2007 and September 2017. Ten to 12 cows with the closest calving dates to one another were selected each year and evaluated for $\mathrm{RFI}_{\text {Lac-Full }}$ as part of a larger study (Connor et al., 2013) in which $\mathrm{RFI}_{\text {Lac100DIM }}$ was estimated for all cows in the BARC herd. Data collection began as soon as possible after calving (mean $\pm \mathrm{SD} ; 7 \pm 3 \mathrm{DIM}$ ) and continued throughout the lactation (305 \pm 3 DIM). Cows were housed in a freestall barn (approximately $15 \mathrm{~m} \times 26 \mathrm{~m}$ ) equipped with 30 to 33 GrowSafe 6000 Feed Intake System feeding troughs (GrowSafe Systems Ltd., Airdrie, AB, Canada) to record individual daily feed intakes. Troughs were arranged in a single line along the front of the freestall barn such that any cow could access any feed trough.

The feeding system uses radio-frequency-based animal identification to detect and record each cow and her feed intake at each trough at any given time by her electronic ear tag. Restriction bars located at the trough opening placed at the appropriate distance limit access to feed to a single animal per visit. GrowSafe software tabulates and reports daily feed intake (as fed) of each cow on a 24 -h basis.

Cows had ad libitum access to a TMR consisting of approximately $39 \%$ corn silage, $30 \%$ grain mix (primarily ground corn and soybean), $16 \%$ haylage, $3.1 \%$ alfalfa hay, $2.3 \%$ orchard grass hay, $2.1 \%$ whole cottonseed, $1.2 \%$ wheat straw, $3.5 \%$ sugar blend, and $2.4 \%$ citrus pulp on an as-fed basis. The TMR was mixed twice daily and fed 3 times per day at approximately 0700, 1400, and $1730 \mathrm{~h}$. A representative grab sample of the TMR at each mixing was collected daily and evaluated for DM percentage. Weekly composite samples were analyzed for nutrient content by Cumberland Valley Analytical Services (Hagerstown, MD). The nutrient analysis of the TMR is summarized in Table 1.

Data collection and estimation of $\mathrm{RFI}_{\mathrm{Lac}-\mathrm{Full}}$ were based on methods previously described in Connor et al. (2013). Briefly, cows were weighed every $14 \mathrm{~d}$ immediately after the morning milking and before feeding. Milk weights were recorded electronically at each milking $(2 \times / d)$ and composite samples were collected weekly for determination of fat and protein percentage by Dairy One (Ithaca, NY). Milk sampling was performed at the morning milking in one week and at the evening milking in the following week, and continued to alternate throughout the study.

Data included in the analysis were restricted to DIM 10 to 305 . To be included in the analysis, feed intake and milk composition data had to meet the following quality control criteria: daily DMI of at least $9 \mathrm{~kg}$ to exclude partial days of intake measurement (e.g., if a cow was temporarily moved out of the pen for veterinary 
Table 1. Composition (mean $\pm \mathrm{SD}$ ) of experimental diets fed to dairy cattle for estimation of residual feed intake at each production stage

\begin{tabular}{|c|c|c|c|c|}
\hline \multirow[b]{2}{*}{ Composition $^{1}$} & \multirow{2}{*}{$\begin{array}{l}\text { Growing heifers } \\
\quad \mathrm{n}=226\end{array}$} & \multicolumn{2}{|c|}{$\begin{array}{l}\text { Growing heifers with lactation data } \\
\text { (to } 100 \mathrm{DIM}) \mathrm{n}=130\end{array}$} & \multirow{2}{*}{$\begin{array}{l}\text { Full-lactation cows } \\
\mathrm{n}=118\end{array}$} \\
\hline & & Growth & Lactation & \\
\hline $\mathrm{CP}(\%$ of $\mathrm{DM})$ & $13.7 \pm 1.2$ & $13.7 \pm 1.3$ & $16.9 \pm 0.8$ & $16.7 \pm 0.8$ \\
\hline Adjusted protein (\% of DM) & $13.5 \pm 1.4$ & $13.5 \pm 1.5$ & $16.9 \pm 0.8$ & $16.7 \pm 0.8$ \\
\hline Soluble protein $(\%$ of $\mathrm{CP})$ & $33.6 \pm 5.8$ & $32.2 \pm 5.7$ & $40.6 \pm 4.6$ & $32.6 \pm 6.1$ \\
\hline $\mathrm{NE}_{\mathrm{M}}(\mathrm{Mcal} / \mathrm{kg})$ & $1.39 \pm 0.05$ & $1.39 \pm 0.06$ & $1.74 \pm 0.05$ & $1.74 \pm 0.05$ \\
\hline $\mathrm{NE}_{\mathrm{G}}(\mathrm{Mcal} / \mathrm{kg})$ & $0.81 \pm 0.05$ & $0.81 \pm 0.05$ & $1.12 \pm 0.04$ & $1.12 \pm 0.05$ \\
\hline $\mathrm{ADF}(\%$ of $\mathrm{DM})$ & $33.6 \pm 1.9$ & $33.6 \pm 2.1$ & $22.0 \pm 1.8$ & $21.0 \pm 1.8$ \\
\hline NDF ( $\%$ of DM) & $51.0 \pm 2.6$ & $50.9 \pm 2.7$ & $33.2 \pm 2.5$ & $32.6 \pm 2.4$ \\
\hline Ash (\% of DM) & $7.1 \pm 0.7$ & $7.3 \pm 0.6$ & $7.6 \pm 0.6$ & $7.5 \pm 0.6$ \\
\hline $\mathrm{NFC}(\%$ of $\mathrm{DM})$ & $27.8 \pm 2.3$ & $27.4 \pm 2.4$ & $41.9 \pm 2.1$ & $40.7 \pm 2.5$ \\
\hline
\end{tabular}

${ }^{1}$ Representative 500-g samples of the TMR collected daily and composited on a weekly basis for nutrient analysis.

treatment, and so on) and milk fat percentage $<7.0$. All milk protein percentages were within the normal range $(\leq 4.7 \%)$. Once these criteria were applied, the (mean $\pm \mathrm{SD}$ ) number of daily observations of DMI (used to calculated ME intake) and milk yield per cow for estimating $\mathrm{RFI}_{\text {Lac-Full }}$ averaged $283 \pm 7$, and the minimum number of daily observations per cow was 257 (out of a possible 295).

Daily estimates of milk fat and protein percentages for each milking period and daily BW for each cow were predicted by fitting a linear model to individual periodic measures as previously described (Connor et al., 2013). Daily ECM yield was calculated from the sum of the predicted (pred) morning and evening milk component values using the equation $\mathrm{ECM}$ yield = $(0.327 \times$ daily milk, $\mathrm{kg})+\left(12.95 \times\right.$ fat $\left._{\text {pred }}, \mathrm{kg}\right)+(7.2$ $\times$ protein $\left._{\text {pred }}, \mathrm{kg}\right)$ from Orth (1992).

The MIXED procedure (SAS Institute Inc., Cary, $\mathrm{NC}$ ) was used to predict average ME intake for each cow by fitting the following regression model:

$$
\begin{gathered}
\text { predicted energy intake }=\mathrm{b}_{0}+\text { year } \times \text { season } \\
+\mathrm{b}_{1} \times \text { metabolic } \mathrm{BW}+\mathrm{b}_{2} \times \mathrm{ADG}+ \\
\mathrm{b}_{3} \times \mathrm{ECM}+\mathrm{e}
\end{gathered}
$$

where $\mathrm{b}_{0}=$ intercept; year $\times$ season $=$ independently and identically distributed random effect of experimental year and season; $b_{1}=$ partial regression coefficient of intake on average predicted metabolic $\mathrm{BW}\left(\mathbf{B W}^{0.75}\right.$, $\mathrm{kg}) ; \mathrm{b}_{2}=$ partial regression coefficient of intake on ADG $(\mathrm{kg} / \mathrm{d}) ; \mathrm{b}_{3}=$ partial regression coefficient of intake on average ECM yield $(\mathrm{kg} / \mathrm{d})$; and e = independently and identically distributed random residuals. The combination of experimental year and season were specified as
CLASS variables. Year was represented by 10 groups, and season was represented by 2 groups (season $1=$ September to March calving date; season $2=$ April to August calving date). Parity was not included in the regression model for predicting $\mathrm{ME}$ intake because its effect was not significant $(P=0.20)$. Ideally the interaction of parity $\times$ ADG should be tested because the composition of gain, and therefore energy requirements may differ among parities. However, due to the small number of multiparous cows in our study, the interaction term was not included in the model. Finally, RFI (Mcal of ME/d) for each animal was calculated as the difference between actual and predicted average energy intakes.

\section{Phenotypic Correlations Between RFI Lac-Full Versus Estimates Over Shorter Periods Within a Lactation}

Stepwise Analysis. Using only data from the 118 whole-lactation cows, Pearson correlations were calculated using SAS 9.4 (SAS Institute Inc.) between $\mathrm{RFI}_{\text {Lac-Full }}$ (10 to 305 DIM) and RFI based on data from moving, 28-d windows within the lactation, beginning at 10 DIM (i.e., whole-lactation $\mathrm{RFI}_{\mathrm{Lac}}$ vs. $\mathrm{RFI}_{\mathrm{Lac}}$ during DIM 10 to 38; vs. DIM 11 to 39; ... vs. DIM 277 to $305)$. For analysis over 28 -d periods, all available data from the whole lactation period were used to estimate daily $\mathrm{BW}$ and daily milk components, then applied to the 28-d period to calculate ADG, metabolic BW, and ECM for model fitting and estimation of $\mathrm{RFI}_{\text {Lac-Full. }} \mathrm{A}$ second-order polynomial regression was fitted to the resulting correlations using Proc GLM (SAS Institute Inc.) to identify the $28-\mathrm{d}$ periods which provided the RFI most predictive of $\mathrm{RFI}_{\mathrm{Lac}-\mathrm{Full}}$. These 28-d period $\mathrm{RFI}$ identified as the most predictive of $\mathrm{RFI}_{\mathrm{Lac}-F u l l}$ were 
TMR is presented in Table 1. Heifers were adjusted to the pen and automated feeders for at least $21 \mathrm{~d}$, followed by a 91-d test period. Heifers were (mean \pm SD) $10.6 \pm 0.1 \mathrm{mo}$ of age at the start of the growth test. Heifers were weighed upon arrival at the test barn and weekly thereafter before feeding at approximately $1330 \mathrm{~h}$.

Daily BW for each heifer was predicted $\left(\mathbf{B W}_{\text {pred }}\right)$ by fitting a linear model of individual weekly BW using the equation:

$$
\mathrm{BW}_{\text {pred }}=\beta_{0}+\beta_{1} \times \mathrm{DAY}+\beta_{2} \times(\mathrm{DAY})^{2},
$$

where $\beta_{0}=$ intercept, and $\beta_{1}$ and $\beta_{2}=$ coefficients for linear and quadratic effects of test day (DAY), respectively. The growth curve of all heifers had a coefficient of determination $\left(\mathbf{R}^{2}\right) \geq 0.90$, and averaged (mean $\pm \mathrm{SD}$ ) $0.96 \pm 0.02$, indicating normal growth. Using $\mathrm{BW}_{\text {pred }}$ values, $\mathrm{ADG}$ was calculated by subtracting $\mathrm{BW}_{\text {pred }}$ on the first test day from $\mathrm{BW}_{\text {pred }}$ on the last test day and dividing by the number of days in the test period. Midtest $\mathrm{BW}$ was the daily $\mathrm{BW}_{\text {pred }}$ at the middle of the test period. Residual feed intake $\left(\mathrm{RFI}_{\text {Growth }}\right)$ was calculated as the difference between actual energy intake (Mcal of $\mathrm{ME} / \mathrm{d}$ ) and that predicted from multiple linear regression of ME intake on mid-test $\mathrm{BW}^{0.75}$ and $\mathrm{ADG}$. The regression model was

$$
\begin{gathered}
\text { predicted energy intake }(\text { Mcal of } \mathrm{ME} / \mathrm{d})=\beta_{0}+\beta_{1} \\
\times \text { mid-test } \mathrm{BW}^{0.75}+\beta_{2} \times \mathrm{ADG}+\mathrm{e}
\end{gathered}
$$

Table 3. Characteristics of Holstein dairy heifers $(\mathrm{n}=130)$ evaluated

\begin{tabular}{|c|c|}
\hline Characteristic & Mean $\pm \mathrm{SE}$ \\
\hline \multicolumn{2}{|l|}{$\mathrm{RFI}_{\text {Growth }}$} \\
\hline Age at start of growth test $(\mathrm{d} \pm \mathrm{SD})$ & $322 \pm 3$ \\
\hline Mid-test $\mathrm{BW}^{1}(\mathrm{~kg})$ & $366 \pm 2$ \\
\hline $\mathrm{ADG}(\mathrm{kg} / \mathrm{d})$ & $0.96 \pm 0.01$ \\
\hline DMI $(\mathrm{kg} / \mathrm{d})$ & $8.5 \pm 0.1$ \\
\hline ME intake (Mcal/d) & $19.98 \pm 0.15$ \\
\hline \multicolumn{2}{|l|}{$\mathrm{RFI}_{\text {Lac100DIM }}$} \\
\hline Age at calving $(\mathrm{d} \pm \mathrm{SD})$ & $734 \pm 38$ \\
\hline $\mathrm{BW}^{2}(\mathrm{~kg})$ & $547 \pm 4$ \\
\hline $\mathrm{ADG}(\mathrm{kg} / \mathrm{d})$ & $0.25 \pm 0.03$ \\
\hline DMI $(\mathrm{kg} / \mathrm{d})$ & $18.6 \pm 0.2$ \\
\hline ME intake (Mcal/d) & $52.19 \pm 0.32$ \\
\hline $\mathrm{ECM}^{3}(\mathrm{~kg} / \mathrm{d})$ & $39.2 \pm 0.4$ \\
\hline
\end{tabular}
for residual feed intake during growth $\left(\mathrm{RFI}_{\text {Growth }}\right)$ and their first lactation up to $100 \mathrm{DIM}\left(\mathrm{RFI}_{\text {Lac100DIM }}\right)$

${ }^{1}$ Predicted $\mathrm{BW}$ at mid-test from regression $\mathrm{BW}=\mathrm{DAY}+\mathrm{DAY}^{2}$ and predicted $\mathrm{BW}=$ intercept $+($ est_DAY $\times \mathrm{DAY})+($ est_DAY $\times$ $\mathrm{DAY}^{2}$ ).

${ }^{2}$ Predicted $\mathrm{BW}$ from regression $\mathrm{BW}=\mathrm{DIM}+\mathrm{DIM}^{2}$ and predicted $\mathrm{BW}=$ intercept $+($ est_DIM $\times \mathrm{DIM})+\left(\right.$ est_DIM $\left.\times \mathrm{DIM}^{2}\right)$.

${ }^{3}$ Energy-corrected milk yield $=(0.327 \times \mathrm{kg}$ of milk $)+(12.95 \times \mathrm{kg}$ of milk fat $)+(7.2 \times \mathrm{kg}$ of milk protein $)$. where $\beta_{0}=$ intercept; $\beta_{1}=$ partial regression coefficient of intake on average mid-test metabolic BW; $\beta_{2}=$ partial regression coefficient of intake on ADG $(\mathrm{kg} / \mathrm{d})$; and $\mathrm{e}$ is the error term. The effects of year and season on the multiple regression model were not significant and, therefore, were not included in the model.

Heifers $(\mathrm{n}=130)$ then were evaluated for $\mathrm{RFI}_{\mathrm{Lac100DIM}}$ in their first lactation between January 2015 and February 2018 per methods described in Connor et al. (2013), but excluding parity from the model for predicting ME intake as only first-lactation animals were included in the analysis. The effects of year and season on the multiple regression model to predict energy were not significant and, therefore, were not included in the model. Diet composition during lactation was the same as that described for full-lactation cows and the nutrient analysis is summarized in Table 1. Characteristics of the Holstein heifers used to assess $\mathrm{RFI}_{\text {Growth }}$ are summarized in Table 2, and the subset of heifers used to evaluate the relationship between $\mathrm{RFI}_{\text {Growth }}$ and $\mathrm{RFI}_{\text {Lac100DIM }}$ in the first lactation are summarized in Table 3.

Correlation between estimates of $\mathrm{RFI}_{\text {Growth }}$ versus $\mathrm{RFI}_{\text {Lac100DIM }}$ estimated from the same 130 heifers were analyzed using SAS 9.4 (SAS Institute Inc.). Animals were categorized into groups by RFI value where RFI $>0.5$ standard deviations below the mean of $0=$ high efficiency, $>0.5$ standard deviations above the mean $=$ low efficiency, and \pm 0.5 standard deviations of the mean $=$ mid efficiency. Means comparisons of phenotypes among the high-, mid-, and low-efficiency groups of growing heifers and full-lactation cows were made by ANOVA using the GLM procedure (SAS Institute Inc.). Further pairwise comparisons of least squares means across groups were performed using the PDIFF option in the LSMEANS statement. Means comparisons of phenotypes between low- and high-efficiency groups were made by a Student's $t$-test. A $P$-value $<0.05$ was considered significant for all statistical inferences.

\section{RESULTS}

\section{Phenotypic Variation in $R \mathrm{RI}_{\text {Lac-Full }}$ and $R \mathrm{RI}_{\text {Growth }}$}

Details of parameter estimates of variables included in the multiple regression models for predicting average ME intake at each production stage are available as Supplemental Table S1 (https://doi.org/10.3168/jds .2018-15407). Regression coefficients of estimated ME intake on mid-test metabolic BW among growing heifers ranged from 0.16 to $0.18 \mathrm{Mcal}$ of $\mathrm{ME} / \mathrm{d} \cdot \mathrm{kg}$ of $\mathrm{BW}^{0.75}$, and on average metabolic BW among lactating cows ranged from 0.24 to $0.33 \mathrm{Mcal}$ of $\mathrm{ME} / \mathrm{d} \cdot \mathrm{kg}$ of $\mathrm{BW}^{0.75}$, depending on lactation stage. Regression coefficients of estimated ME intake on ADG ranged from 4.04 to 
$4.52 \mathrm{Mcal}$ of $\mathrm{ME} / \mathrm{d} \cdot \mathrm{kg}$ of $\mathrm{BW}^{0.75}$ among growing heifers and were 3.53 and $2.87 \mathrm{Mcal}$ of $\mathrm{ME} / \mathrm{d} \cdot \mathrm{kg}$ of $\mathrm{BW}^{0.75}$ for first-parity heifers in the first 100 DIM and fulllactation cows, respectively. The regression coefficient of estimated ME intake on ECM was $0.54 \mathrm{Mcal}$ of ME/ $\mathrm{kg}$ for first-parity heifers to 100 DIM and 0.83 Mcal of $\mathrm{ME} / \mathrm{kg}$ for full-lactation cows. Among cows evaluated for $\mathrm{RFI}_{\mathrm{Lac}-F u l l}$, the standard deviation for $\mathrm{RFI}_{\mathrm{Lac}-F u l l}$ was $2.84 \mathrm{Mcal}$ of $\mathrm{ME} / \mathrm{d}$ and the $\mathrm{R}^{2}$ for the model to predict $\mathrm{ME}$ intake was 0.77 . Inclusion of year and season as random effects substantially improved the model $R^{2}$, with a $\mathrm{R}^{2}$ of 0.57 when these effects were not included in the model.

Among whole-lactation cows, average ME intake differed $(P<0.0003)$ among the high-, mid-, and lowefficiency groups, with no differences $(P>0.23)$ in BW, ADG, or ECM yield, as expected (Table 2). Average ME intake differed $(P<0.003)$ by $7.43 \mathrm{Mcal} / \mathrm{d}$ (or $2.7 \mathrm{~kg} / \mathrm{d}$ of DMI) between the low-efficiency and highefficiency cows, with no differences in ADG $(P=0.98)$, ECM $(P=0.41)$, or BW $(P=0.84$; Table 2$)$. Average DMI of the high-efficiency group $(20.5 \mathrm{~kg} / \mathrm{d})$ was $6.0 \%$ less than the herd average $(21.8 \mathrm{~kg} / \mathrm{d}$; Table 2$)$.

Among growing heifers, the standard deviation for $\mathrm{RFI}_{\text {Growth }}$ among all 226 heifers evaluated was $1.37 \mathrm{Mcal}$ of $\mathrm{ME} / \mathrm{d}$ and the $\mathrm{R}^{2}$ for the model to predict ME intake was 0.42 . Average ME intake of growing heifers differed $(P<0.0001)$ among the high-, mid-, and low-efficiency groups, with no differences $(P=0.37)$ in mid-test BW (Table 2). Average ME intake differed $(P<0.0001)$ by $3.01 \mathrm{Mcal} / \mathrm{d}(1.2 \mathrm{~kg} / \mathrm{d}$ of DMI) between high- and lowefficiency heifers $\left( \pm 0.5 \mathrm{SD}\right.$ from mean $\mathrm{RFI}_{\text {Growth }}$ of 0$)$ with no difference in mid-test $\mathrm{BW}(P=0.75)$ or ADG $(P=0.96$; Table 2$)$. The ADG of the mid-efficiency heifers was greater $(P=0.01)$ than the high- and lowefficiency groups. The high- and mid-efficiency heifers exhibited a lower $(P<0.0001)$ feed conversion ratio (FCR; i.e., mean trial daily $\mathrm{DMI} /$ mean trial ADG) compared with the FCR of the low-efficiency heifers. Average DMI of the high-efficiency heifers $(7.9 \mathrm{~kg} / \mathrm{d})$ was $8.1 \%$ less than the herd average $(8.6 \mathrm{~kg} / \mathrm{d}$; Table $2)$.

\section{Phenotypic Correlations Between RFI $_{\text {Lac-Full }}$ Versus Estimates Over Shorter Periods Within a Lactation}

Stepwise Analysis. Figure 1 shows the correlations between $\mathrm{RFI}_{\text {Lac-Full }}$ (based on measurements collected between 10 and 305 DIM) and RFI estimated in the same cows based on data collected within 28-d windows of time beginning at 10 DIM. Pearson correlations between $\mathrm{RFI}_{\text {Lac-Full }}$ and 28-d period RFI ranged from 0.57 to 0.87 . The regression on these correlations indi- cated the 28-d periods with the greatest association to $\mathrm{RFI}_{\text {Lac-Full }}$ occurred between 132 and 232 DIM (predicted $\mathrm{r} \geq 0.80$; maximum predicted $\mathrm{r}=0.81$; Figure 1 ). Focusing on the midpoint of this period (i.e., 182 DIM), we then evaluated correlations between $\mathrm{RFI}_{\text {Lac-Full }}$ and estimates of RFI based on increasing windows of time by 2-d increments from 14 to $110 \mathrm{~d}$ in length surrounding 182 DIM as the midpoint of the sampling period (Figure 2). Thus, a 14-d test period was DIM 175 to 189, a 16-d test period was DIM 174 to $190, \ldots$ to a 110-d test period covering DIM 127 to 237. Correlation coefficients ranged from 0.77 for a 14 -d test period (i.e., DIM 175 to 189 ) to a maximum of 0.93 beyond a test duration of $102 \mathrm{~d}$ in length. The correlation coefficient was $\geq 0.90$ with sampling windows of $64 \mathrm{~d}$ or more in duration, and a sampling period beyond $82 \mathrm{~d}$ in length increased the coefficient by $\leq 0.003$ units with each 2 -d increase in the length of the sampling window. Test durations shorter than $64 \mathrm{~d}$ resulted in corresponding declines in the magnitude of the correlation coefficients, such that test periods of fewer than $42 \mathrm{~d}$ (i.e., between DIM 161 to 203) had a Pearson correlation coefficient $\leq 0.85$ (Figure 2).

Combined Analysis. Pearson correlations between $\mathrm{RFI}_{\text {Lac-Full }}$ versus RFI estimates based on shorter test periods ranged from 0.57 for a 28 -d test period beginning at 10 DIM to a maximum of 0.93 for a 98 -d test period beginning between 108 and 122 DIM (Figure $3)$. Among the test lengths evaluated, the shortest test achieving a correlation of at least 0.90 with $\mathrm{RFI}_{\text {Lac-Full }}$ was $70 \mathrm{~d}$ in duration, beginning between 122 and 150 DIM. Increasing the test period to $84 \mathrm{~d}$ in duration for the same stage of lactation increased the correlation coefficient to 0.91 or 0.92 (Figure 3 ).

Among the 118 cows for which full-lactation data were available, the phenotypic correlation between $\mathrm{RFI}_{\text {Lac100DIM }}$ and $\mathrm{RFI}_{\text {Lac-Full }}$ was $0.72(P<0.0001$; Figure 4). Specifically, ranking of these cows as high or low efficiency based on $\mathrm{RFI}_{\text {Lac100DIM }}$ indicated that the highefficiency cows maintained an average DMI of $1.9 \mathrm{~kg} / \mathrm{d}$ less (or $8.3 \%$ less; $P<0.0001$ ) over the whole lactation than the low-efficiency cows (mean \pm SE; $21.0 \pm 0.4$ $\mathrm{kg} / \mathrm{d}$ versus $22.9 \pm 0.4$ ). Despite the lower feed intake, these high-efficiency cows produced similar $(P=0.47)$ average ECM during the whole lactation $(39.7 \pm 0.8$ $\mathrm{kg} / \mathrm{d})$ to the low-efficiency cows $(38.8 \pm 0.9 \mathrm{~kg} / \mathrm{d})$.

\section{Phenotypic Correlation of Heifer RFI Growth to RFI Lac100DIM}

Among the subset of 130 growing heifers for which estimates of $\mathrm{RFI}_{\mathrm{Lac100DIM}}$ in the first lactation were also available, the standard deviation for $\mathrm{RFI}_{\text {Growth }}$ was 1.28 


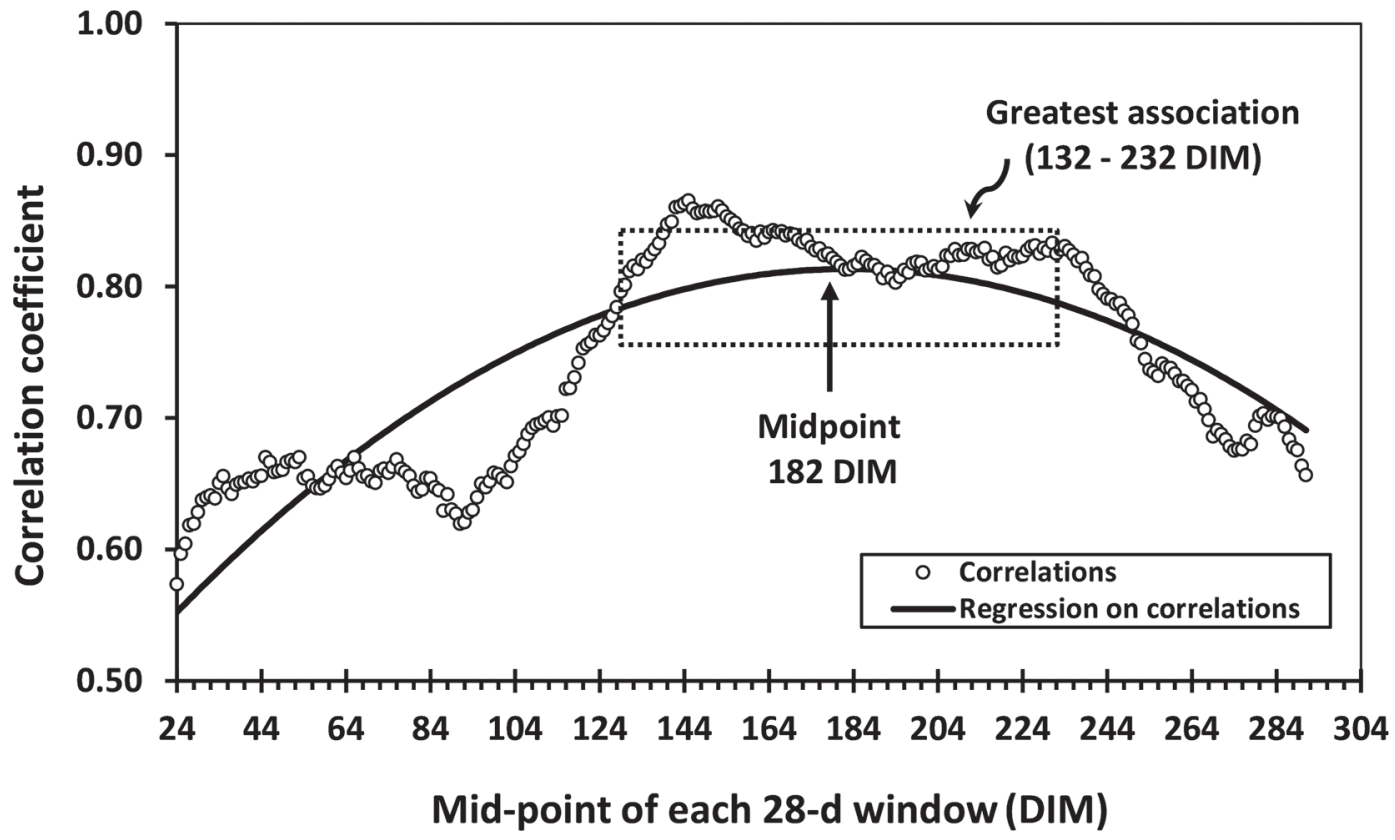

Figure 1. Plot of correlation between residual feed intake (RFI) estimated from data collected during 10 to 305 DIM and RFI estimated from data collected during 28-d windows of time beginning at 10 DIM in Holstein cows $(\mathrm{n}=118)$.

Mcal of ME/d and the $\mathrm{R}^{2}$ for the model to predict ME intake was 0.45 . The standard deviation for $\mathrm{RFI}_{\mathrm{Lac100DIM}}$ was $3.59 \mathrm{Mcal}$ of $\mathrm{ME} / \mathrm{d}$ and the $\mathrm{R}^{2}$ for the model to predict $\mathrm{ME}$ intake was 0.51 . The correlation between $\mathrm{RFI}_{\text {Growth }}$ and $\mathrm{RFI}_{\mathrm{Lac} 100 \mathrm{DIM}}$ of these heifers was $0.37(P$ $<0.0001$; Figure 5A). Among the low- $(>0.5 \mathrm{SD}$ above the mean), mid-, and high-efficiency ( $>0.5 \mathrm{SD}$ below the mean) heifers based on $\mathrm{RFI}_{\text {Growth }}$, only $43 \%$ maintained their classification based on $\mathrm{RFI}_{\mathrm{Lac100DIM}}$ (Figure $5 \mathrm{~A})$. Mean $\mathrm{RFI}_{\text {Growth }}$ of the low-efficiency heifers was

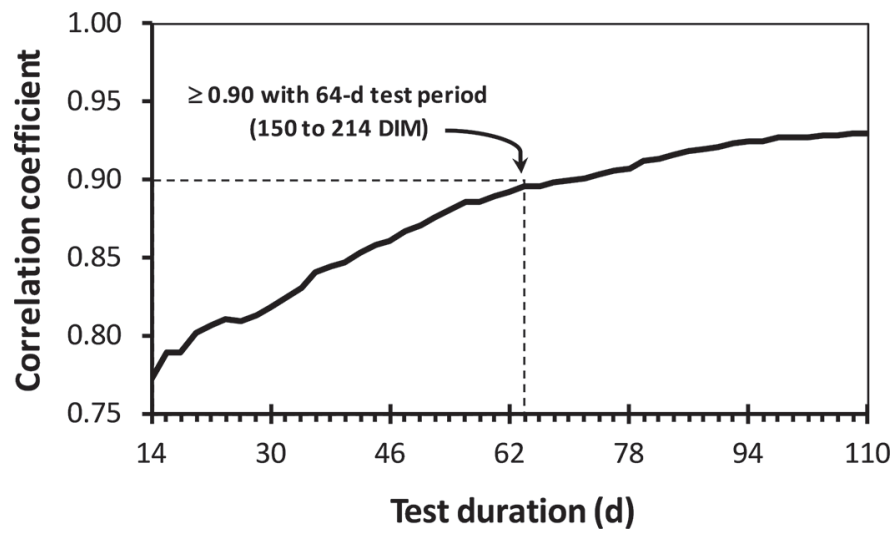

Figure 2. Plot of correlation between residual feed intake (RFI) estimated from data collected during 10 to 305 DIM and RFI estimated from data collected during increasing windows of time from 14 to $110 \mathrm{~d}$ in length surrounding 182 DIM as the midpoint of the sampling period in Holstein cows $(\mathrm{n}=118)$.
1.28 Mcal of ME/d and that of the high-efficiency heifers was $-1.57 \mathrm{Mcal}$ of $\mathrm{ME} / \mathrm{d}$ (Table 3 ); thus, a difference in $\mathrm{RFI}_{\text {Growth }}$ of $2.85 \mathrm{Mcal}$ of $\mathrm{ME} / \mathrm{d}$ between the divergent groups $(P<0.0001)$. Average ME intake of these 130 growing heifers was $19.98 \mathrm{Mcal} / \mathrm{d}$ (Table 3), indicating a divergence of $14 \%$ in $\mathrm{RFI}_{\text {Growth }}$ between the least and most efficient groups.

On average, the high-efficiency heifers (based on low $\mathrm{RFI}_{\text {Growth }}$ ) consumed $3.27 \mathrm{Mcal}$ of ME/d less (or $1.19 \mathrm{~kg}$ of DM/d less) during the first 100 DIM than the low-efficiency heifers $\left[50.56 \mathrm{Mcal}\right.$ of $\mathrm{ME} / \mathrm{d}$ (low $\mathrm{RFI}_{\text {Growth }}$ ) vs. $53.83 \mathrm{Mcal}$ of $\mathrm{ME} / \mathrm{d}$ (high $\mathrm{RFI}_{\text {Growth }}$ ); $P<0.005$; Figure $5 \mathrm{~B}]$, but exhibited no differences in average ECM [38.6 $\mathrm{kg} / \mathrm{d}$ (low $\mathrm{RFI}_{\text {Growth }}$ ) vs. $39.4 \mathrm{~kg} / \mathrm{d}$ (high $\mathrm{RFI}_{\text {Growth }}$ ); $P=0.51]$, ADG $\left[0.30 \mathrm{~kg} / \mathrm{d}\left(\right.\right.$ low $\left.\mathrm{RFI}_{\text {Growth }}\right)$ vs. 0.26 $\mathrm{kg} / \mathrm{d}$ (high $\mathrm{RFI}_{\text {Growth }}$ ); $P=0.57$ ], or BW [539 kg (low $\mathrm{RFI}_{\text {Growth }}$ ) vs. $547 \mathrm{~kg}$ (high $\mathrm{RFI}_{\text {Growth }}$ ); $P=0.44$ ] during the first 100 DIM. The least efficient heifers identified during the growth test had a $\mathrm{RFI}_{\mathrm{Lac100DIM}}$ value of 1.51 Mcal of ME/d, and the most efficient heifers during the growth trial had a $\mathrm{RFI}_{\text {Lac100DIM }}$ value of $-1.12 \mathrm{Mcal}$ of $\mathrm{ME} / \mathrm{d}$ (difference of $2.63 \mathrm{Mcal}$ of $\mathrm{ME} / \mathrm{d} ; P<0.001$; Figure 5C). Average ME intake of heifers through 100 DIM in the first lactation was $52.19 \mathrm{Mcal} / \mathrm{d}$, indicating that during the first 100 DIM the groups maintained a divergence of $5 \%$ in $\mathrm{RFI}_{\mathrm{Lac100DIM}}$. Average $\mathrm{ME}$ intake of the low $\mathrm{RFI}_{\text {Growth }}$ group during the first 100 DIM was $3.1 \%$ lower than the herd average, which equated to a difference of $0.59 \mathrm{~kg}$ of $\mathrm{DM} / \mathrm{d}$ (or $1.21 \mathrm{~kg} / \mathrm{d}$ as fed). 


\begin{tabular}{|c|c|c|c|c|c|c|}
\hline \multirow{2}{*}{$\begin{array}{c}\text { DIM } \\
\text { at start }\end{array}$} & \multicolumn{6}{|c|}{ Test duration (d) } \\
\hline & 28 & 42 & 56 & 70 & 84 & 98 \\
\hline 10 & 0.57 & 0.63 & 0.67 & 0.69 & 0.71 & 0.73 \\
\hline 24 & 0.65 & 0.70 & 0.71 & 0.72 & 0.74 & 0.78 \\
\hline 38 & 0.67 & 0.68 & 0.69 & 0.72 & 0.76 & 0.79 \\
\hline 52 & 0.67 & 0.68 & 0.71 & 0.75 & 0.79 & 0.84 \\
\hline 66 & 0.65 & 0.68 & 0.73 & 0.77 & 0.83 & 0.87 \\
\hline 80 & 0.63 & 0.70 & 0.76 & 0.82 & 0.87 & 0.90 \\
\hline 94 & 0.69 & 0.76 & 0.82 & 0.87 & 0.89 & 0.92 \\
\hline 108 & 0.76 & 0.82 & 0.87 & 0.89 & 0.91 & 0.93 \\
\hline 122 & 0.82 & 0.87 & 0.88 & 0.90 & 0.92 & 0.93 \\
\hline 136 & 0.86 & 0.86 & 0.89 & 0.90 & 0.91 & 0.92 \\
\hline 150 & 0.84 & 0.87 & 0.89 & 0.90 & 0.91 & 0.91 \\
\hline 164 & 0.82 & 0.85 & 0.87 & 0.89 & 0.90 & 0.90 \\
\hline 178 & 0.81 & 0.84 & 0.86 & 0.88 & 0.88 & 0.88 \\
\hline 192 & 0.82 & 0.85 & 0.86 & 0.87 & 0.87 & 0.87 \\
\hline 206 & 0.83 & 0.85 & 0.85 & 0.85 & 0.86 & 0.86 \\
\hline 220 & 0.83 & 0.83 & 0.82 & 0.83 & 0.83 & \\
\hline 234 & 0.78 & 0.77 & 0.78 & 0.79 & & \\
\hline 248 & 0.73 & 0.74 & 0.75 & & & \\
\hline 262 & 0.68 & 0.71 & & & & \\
\hline 276 & 0.66 & & & & & \\
\hline
\end{tabular}

\begin{tabular}{|c|c|}
\multicolumn{1}{c}{$\begin{array}{c}\text { Correlation } \\
\text { coefficient }\end{array}$} \\
\hline & $<0.70$ \\
\hline & $0.70-0.74$ \\
\hline & $0.75-0.79$ \\
\hline & $0.80-0.84$ \\
\hline & $0.85-0.89$ \\
\hline & $0.90-0.92$ \\
\hline$>0.92$ \\
\hline
\end{tabular}

Figure 3. Pearson correlation matrix for residual feed intake (RFI) estimated using data collected during 10 to 305 DIM versus RFI estimated using data collected during shorter windows of time and beginning at different stages of the lactation period in Holstein cows $(\mathrm{n}=118)$.

\section{DISCUSSION}

\section{Evaluation of Models Used to Estimate ME Intake}

It is important to keep in mind that feed efficiency based on RFI (i.e., the difference between actual and predicted energy intake) is not a direct measurement of efficiency, but rather is an estimate based on a model error term. Thus, an animal's RFI value reflects an estimate of its metabolic efficiency relative to the average animal in the cohort using variables included in the model and their associated measurement errors, plus any errors in fitting the model itself. For example, errors in measurement of ADG and BW include factors such as gut fill and body composition. Likewise, calculations of ECM yield using formulas based on milk fat and protein percentages and milk weight have inherent errors. Although automated systems and radiofrequency identification technology have improved the accuracy and precision of measuring individual DMI of dairy cattle, errors associated with determining actual energy intake for calculating RFI also exist. These include minor errors in the feed weights assigned to each animal (e.g., due to feed spillage during consumption), errors in estimating ME intake based on dietary TDN\%, or even potential sorting of specific dietary ingredients by individual cows affecting the energy of the diet consumed. Thus, in conducting our trials, sampling, measurements, animal management, and quality control of data were designed and conducted to minimize the cumulative effects of these inherent measurement errors.

Regarding model fit errors, any factor affecting animal feed intake not accounted for in the model also

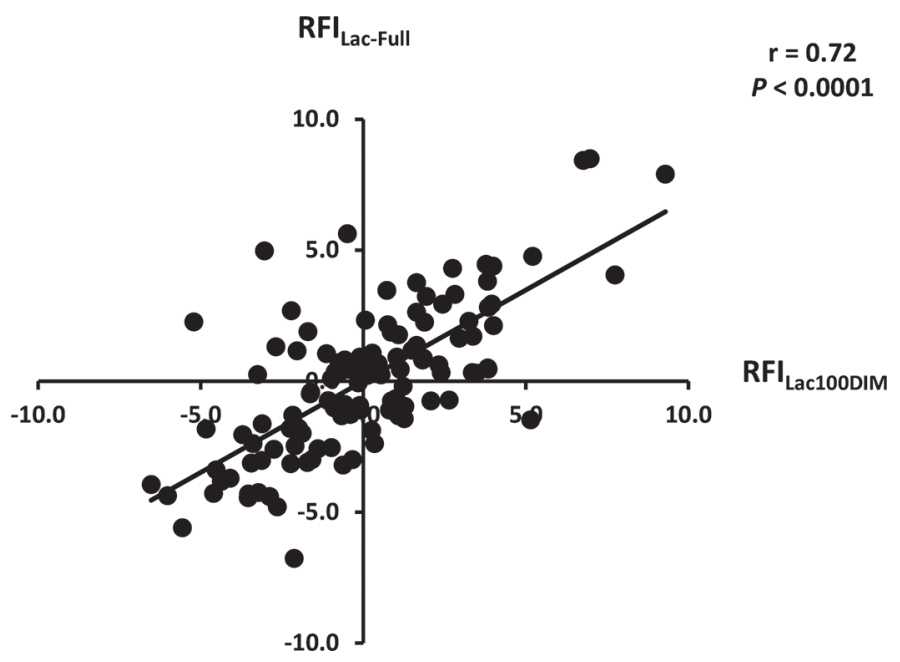

Figure 4. Correlation of residual feed intake (RFI; Mcal of ME/d) estimated during the first $100 \mathrm{DIM}\left(\mathrm{RFI}_{\mathrm{Lac100DIM}}\right)$ versus the same cows during the full, 305-d lactation $\left(\mathrm{RFI}_{\mathrm{Lac}-F u l l} ; \mathrm{n}=118\right)$. 


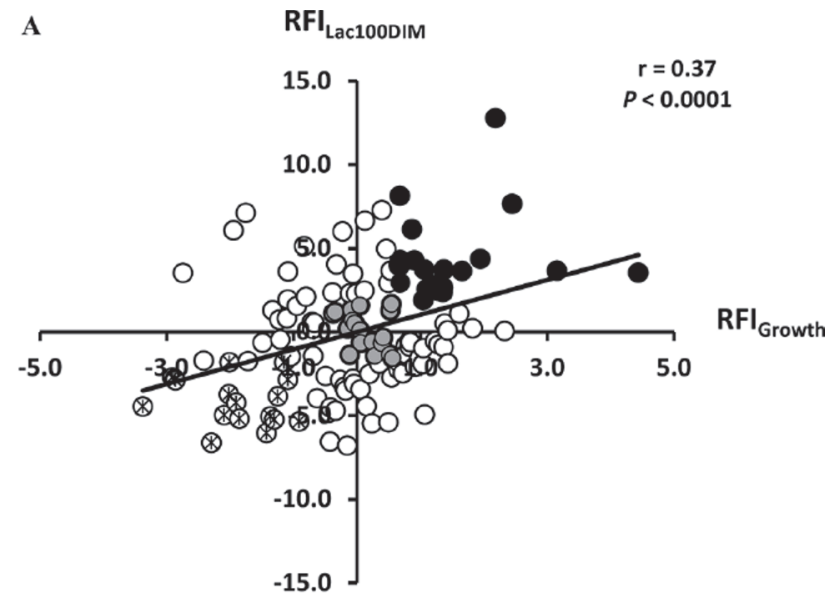

B

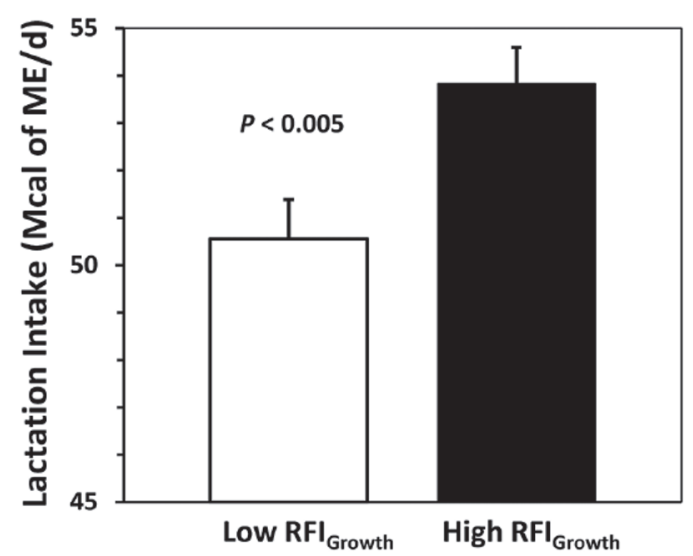

C

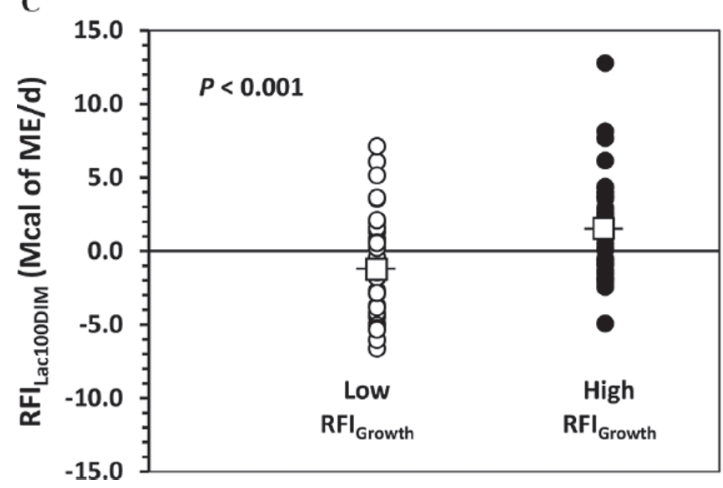

Figure 5. Correlation of residual feed intake (RFI; Mcal of ME/d) estimated among heifers during a 91-d growth trial beginning at approximately 10 mo of age $\left(\mathrm{RFI}_{\text {Growth }}\right)$ versus RFI estimated in the same animals during the first $100 \mathrm{DIM}$ of the first lactation $\left(\mathrm{RFI}_{\mathrm{Lac100DIM}}\right.$; $\mathrm{n}=130$; panel A). Heifers that maintained their classification as low ( $>0.5 \mathrm{SD}$ above the mean), mid ( $\pm 0.5 \mathrm{SD}$ of mean), or high efficiency $(>0.5 \mathrm{SD}$ below the mean) in both production stages are represented by black circles $(\mathrm{n}=21)$, gray circles $(\mathrm{n}=18)$, or circles containing an asterisk $(\mathrm{n}=17)$, respectively. Average observed ME intake $\left( \pm \mathrm{SE}\right.$; panel B) during the first $100 \mathrm{DIM}$, and $\mathrm{RFI}_{\text {Lac100DIM }}$ (panel C) of primiparous cows that were divergent in $\mathrm{RFI}_{\text {Growth }}$ as heifers. Low $\mathrm{RFI}_{\text {Growth }}:>0.5 \mathrm{SD}$ below the mean $\left(\mathrm{n}=37\right.$; efficient); high $\mathrm{RFI}_{\text {Growth }}$ : $>0.5 \mathrm{SD}$ above the mean $(\mathrm{n}=44$; inefficient). Individual circles in panel $\mathrm{C}$ represent $\mathrm{RFI}_{\text {Lac100DIM }}$ values of individual primiparous cows and open boxes with horizontal lines represent the mean $\mathrm{RFI}_{\mathrm{Lac100DIM}}$ values of the divergent $\mathrm{RFI}_{\text {Growth }}$ groups. contributes to the residual error term. For instance, because energy required for a unit of $\mathrm{BW}$ gain is greater than energy produced for the same unit of BW loss, accounting for each form of BW change separately may provide a better model fit compared with overall ADG. In the present study, because most cows gained weight over the lactation and the limited size of our data set, only ADG was included in our model as opposed to separate variables of $\mathrm{BW}$ loss and gain. Despite the limitations mentioned above and differences in models used across studies to estimate RFI, it has become a common method to estimate feed efficiency and rank performance of lactating cattle.

Based on NRC (2001) values for the energy requirements for milk production and maintenance of dairy cattle, the partial regression coefficients obtained in our models for predicting ME intake were not biologically meaningful. Therefore, these coefficients cannot be applied to an independent data set. Specifically, the coefficients for metabolic BW were too high and for ECM were too low, meaning that our model overestimated variability in energy intake assigned to metabolic BW and underestimated variability assigned to ECM. This is not uncommon, particularly in studies modeling relatively small numbers of animals.

In a similar study of first-parity heifers evaluated for $\mathrm{RFI}_{\mathrm{Lac100DIM}}$, the partial regression coefficients for metabolic BW, ADG, and ECM were $0.13 \mathrm{Mcal}$ of ME/ $\mathrm{kg}$ of $\mathrm{BW}^{0.75}, 2.32 \mathrm{Mcal}$ of $\mathrm{ME} / \mathrm{kg}$, and $0.48 \mathrm{Mcal}$ of $\mathrm{ME} / \mathrm{kg}$, respectively (VanArendonk et al., 1991). The authors indicated the coefficient for metabolic BW was near the expected value of 0.12 , but those for ADG and ECM were lower than actual animal requirements. For comparison, our coefficients were 0.33 Mcal of ME $/ \mathrm{kg}$ of $\mathrm{BW}^{0.75}, 3.53 \mathrm{Mcal}$ of $\mathrm{ME} / \mathrm{kg}$, and $0.54 \mathrm{Mcal}$ of ME/ $\mathrm{kg}$ for metabolic BW, ADG, and ECM, respectively, in the first 100 DIM. Using a factor of 0.64 to convert ME to $\mathrm{NE}_{\mathrm{L}}$, expected ECM is approximately 1.16 Mcal of $\mathrm{ME} / \mathrm{kg}$ (NRC, 2001).

Using the same conversion factor, partial regression coefficients for net energy intake on metabolic BW, weight change, and solids-corrected milk production reported by Ngwerume and Mao (1992) for US Holstein cows of mixed parities throughout a full lactation converted to $\mathrm{ME}$ intakes of approximately $0.23 \mathrm{ME} /$ $\mathrm{kg}$ of $\mathrm{BW}^{0.75}, 2.38 \mathrm{Mcal}$ of $\mathrm{ME} / \mathrm{kg}$, and 0.84 Mcal of $\mathrm{ME} / \mathrm{kg}$, respectively. Our values for full-lactation cows were similar at $0.24,2.87$, and 0.83 , respectively. Overall, because our intercepts for lactating cows were large and negative $(-1.51$ and -7.24$)$, and relatively large and positive (0.74 and 2.11) for growing heifers (see Supplemental Table S1; https://doi.org/10.3168/ jds.2018-15407), these intercept values contributed to 
over- or underestimation of coefficients for the other variables in the model.

\section{Phenotypic Variation in $\mathrm{RFI}_{\text {Lac-Full }}$ and $\mathrm{RFI}_{\text {Growth }}$}

The fit $\left(\mathrm{R}^{2}=0.77\right)$ of our model for estimating $\mathrm{RFI}_{\text {Lac-Full }}$ was within the range of values reported in previous studies of lactating cows fed a TMR, which ranged from 0.68 to 0.93 (reviewed by Fischer et al. [2018]). The observed variation in $\mathrm{RFI}_{\text {Lac-Full }}(\mathrm{SD}=3.91$ Mcal of ME/d), based primarily on first-parity cows, was similar to variation reported in a previous study among first-parity cows from the same Holstein herd in which RFI was estimated during only the first 90 DIM ( $\mathrm{SD}=3.47 \mathrm{Mcal}$ of ME/d; Connor et al., 2013). This variation in RFI and its low-to-moderate heritability (Berry and Crowley, 2013) indicate an opportunity to improve RFI of lactating cows through selection. Manafiazar et al. (2013) reported a standard deviation in RFI of $2.42 \mathrm{Mcal}$ of $\mathrm{NE}_{\mathrm{L}} / \mathrm{d}$ [or approximately $3.78 \mathrm{Mcal}$ of ME/d using a conversion factor of 0.64 from NRC (2001)] in Canadian primiparous dairy cows evaluated during a complete lactation; however, their cows were managed in a tiestall system, and were fed rations that differed in energy density depending on milk production level. Our US Holsteins were managed in a freestall environment and fed a constant TMR. Additionally, predicted $\mathrm{NE}_{\mathrm{L}}$ intake in the study by Manafiazar et al. (2013) for calculating RFI was based on orthogonal polynomial random regression. These differences in experimental design between the 2 studies may influence the observed difference in variation in RFI. Overall, our standard deviation for $\mathrm{RFI}_{\text {Lac-Full }}$ expressed as percentage of mean ME intake was $6.4 \%$ (i.e., $3.91 \mathrm{Mcal}$ of $\mathrm{ME} / \mathrm{d} / 61.45 \mathrm{Mcal} / \mathrm{d} \times 100)$. This is also in line with RFI variability estimates calculated by Fischer et al. (2018) for 6 previously published studies of lactating cows where the CV for RFI ranged from 2.8 to $9.4 \%$.

Our results indicate that selection of cows with the lowest $\mathrm{RFI}_{\mathrm{Lac}-\mathrm{Full}}$, particularly among first-parity cows, could reduce feed intake by $6.0 \%$ (i.e., $1.3 \mathrm{~kg}$ of $\mathrm{DM} / \mathrm{d}$ or $2.6 \mathrm{~kg} / \mathrm{cow} \cdot \mathrm{d}^{-1}$ as fed) based on the observed difference in mean DMI between the high-efficiency cows and the overall group average during a 305-d lactation. Based on the estimated US May 2018 cost of a 16\% proteinmixed dairy ration of corn, soybeans, and alfalfa hay of $\$ 0.19 / \mathrm{kg}$ of feed as fed $(\$ 8.53 / \mathrm{cwt}$ of feed; USDANASS, 2018), this daily reduction of $2.6 \mathrm{~kg}$ of feed (as fed) per cow would be a savings of $\$ 0.494 / \mathrm{cow} \cdot \mathrm{d}^{-1}$ (or $\$ 150.67 /$ cow lactation $\left.^{-1}\right)$. Note that this assumes the RFI estimate is entirely a reflection of feed efficiency. In fact, RFI is composed partly of errors in measurement of variables included in the multiple regression model, as well as other unexplained error (fitting errors) in the multiple regression model. These errors can be a large proportion of the residual error (Fischer et al., 2018). Overall, estimates indicate that selection of the most efficient cows within the herd based on $\mathrm{RFI}_{\text {Lac-Full }}$ may provide a substantial reduction in feed costs without a reduction in milk yield. The actual savings in feed cost varies depending on how accurately the RFI estimates reflect true cow feed efficiency, as well as the current feed cost for the specific production setting of interest. Savings costs presented here are simplified estimates based on our feed ration and location.

Similar opportunity to improve feed efficiency in growing dairy heifers was found by examining $\mathrm{RFI}_{\text {Growth }}$ in Holstein heifers between 10 and 15 mo of age and fed a TMR. The fit of our model $\left(\mathrm{R}^{2}=0.42\right)$ was below values reported previously for growing cattle of 0.53 to 0.79 (Lancaster et al., 2009; Carnie et al., 2010; Durunna et al., 2012), although addition of year and season to the model did not improve its fit. The observed standard deviation in $\mathrm{RFI}_{\text {Growth }}$ calculated as energy intake in our study was $1.37 \mathrm{Mcal}$ of $\mathrm{ME} / \mathrm{d}$, or $0.59 \mathrm{~kg} / \mathrm{d}$ when calculated as DMI (data not shown) for the sake of comparison to other published studies. Our standard deviation expressed as a percentage of the average heifer ME intake was $6.9 \%$ (i.e., 1.37 Mcal of $\mathrm{ME} / \mathrm{d} / 19.98 \mathrm{Mcal}$ of $\mathrm{ME} / \mathrm{d} \times 100)$. This variation is consistent with reports of $1.17 \mathrm{Mcal}$ of ME/d in Dutch and Holstein-Friesian heifers evaluated between 10 and 14 mo of age (Korver et al., 1991) and $0.54 \mathrm{~kg}$ of DM/d in Holstein-Friesian heifers of approximately 8 mo of age (Carnie et al., 2010). Our variation was slightly greater than reported for younger Holstein-Friesian heifers evaluated between 5 and 7 mo of age of 0.40 to $0.47 \mathrm{~kg}$ of $\mathrm{DM} / \mathrm{d}$ (Williams et al., 2011). Based on actual DMI among our growing heifers, selecting the most efficient animals based on $\mathrm{RFI}_{\text {Growth }}$ could reduce feed intake by an average of $8.1 \%$ over the test period relative to the herd average (i.e., by $0.7 \mathrm{~kg}$ of $\mathrm{DM} / \mathrm{d}$, or $1.62 \mathrm{~kg} / \mathrm{d}$ as fed), with no loss in ADG or mid-test BW. In monetary terms, this is a reduction in feed costs of approximately $\$ 0.21 /$ heifer $\cdot \mathrm{d}^{-1}$ based on our May 2018 heifer ration cost of $\$ 0.13 / \mathrm{kg}$ (as fed) for this growth stage. Again, this assumes the RFI estimate is entirely a reflection of feed efficiency, and is based on defining the most efficient heifers as those with an RFI value of $>0.5$ standard deviations below the mean. It also is based on our specific ration cost. Assuming the most efficient heifers consistently consume less feed relative to the herd average from weaning to prefreshening, this could represent a significant reduction in heifer production costs of which about $60 \%$ are attributed to feed costs (Heinrichs et al., 2016).

Heifers divergent in $\mathrm{RFI}_{\text {Growth }}$ also exhibited significant differences in gross feed efficiency estimated as 
FCR where the most efficient heifers based on $\mathrm{RFI}_{\text {Growth }}$ had a $13.9 \%$ lower FCR relative to the least efficient heifers, or $6.1 \%$ lower FCR relative to the herd average. Similarly, Basarab et al. (2003) reported 9.4\% reductions in FCR of growing beef steers with low $\mathrm{RFI}_{\text {Growth }}$ compared with those with high $\mathrm{RFI}_{\text {Growth }}$. Based on heritability estimates of 0.22 to 0.27 for RFI in growing dairy heifers (Korver et al., 1991; Williams et al., 2011) and observed reductions in DMI and improved FCR in heifers with low $\mathrm{RFI}_{\text {Growth }}$, opportunity exists to reduce feed costs in growing dairy heifers through selection for lower $\mathrm{RFI}_{\text {Growth}}$, without losing weight gains or feed conversion efficiency. Previous research in cattle also suggests that genetic correlations $\left(\mathrm{r}_{\mathrm{g}} \pm \mathrm{SE}\right)$ between $\mathrm{RFI}_{\text {Growth }}$ and ADG $(0.01 \pm 0.13)$, mid-test BW $(-0.18$ $\pm 0.09)$, and FCR $(0.48 \pm 0.10)$ are favorable (Crowley et al., 2010).

\section{Phenotypic Correlations Between RFI $_{\text {Lac-Full }}$ Versus Estimates Over Shorter Periods Within a Lactation}

Because data collection to estimate $\mathrm{RFI}_{\text {Lac-Full }}$ is labor intensive, costly, and time consuming, we used 2 approaches to determine the sampling periods during the lactation that provide the most reliable estimates of $\mathrm{RFI}_{\text {Lac-Full }}$. A stepwise approach first identified the 28-d test windows with the strongest correlations to $\mathrm{RFI}_{\text {Lac-Full }}$. From the midpoint of these periods, we then determined the minimum duration of data collection required to provide reliable estimates of $\mathrm{RFI}_{\text {Lac-Full }}$. We found that a test period of 64 to $74 \mathrm{~d}$ in duration surrounding d 182 of lactation (e.g., 150 to 219 DIM) provided the best approximation (correlation coefficient $\geq 0.90$ ) of $\mathrm{RFI}_{\text {Lac-Full }}$ for the least time and effort among the periods evaluated. Test periods $<64 \mathrm{~d}$ in duration surrounding d 182 of lactation provided less reliable estimates of whole-lactation $\mathrm{RFI}_{\text {Lac }}$, and test periods beyond $82 \mathrm{~d}$ in duration did not provide sufficient improvements to the relationship (i.e., increased correlation coefficient, $r$, by $\leq 0.003$ units for every 2 -d increase in the test period) to warrant the longer test period. A combined approach that examined 6 possible test durations $(28,42,56,70,84$, or $98 \mathrm{~d})$ starting on different days throughout the lactation period indicated that a 70-d test beginning between 122 to 150 DIM provided reliable estimates of $\mathrm{RFI}_{\text {Lac-Full }}(\mathrm{r}=0.90)$. Only small improvements to the relationship were achieved with a test period up to $98 \mathrm{~d}$ in length $(\mathrm{r}=0.91$ to 0.93). Taken together, our analyses suggest that 64 - to 70 -d test periods occurring between approximately 150 and 220 DIM should reduce costs associated with estimating $\mathrm{RFI}_{\text {Lac-Full }}$ and increase the capacity for animal testing on a given farm.
Because we routinely evaluate $\mathrm{RFI}_{\text {Lac100DIM }}$ in our herd, we also wished to determine how well this earlylactation test reflects $\mathrm{RFI}_{\text {Lac-Full }}$. For our estimates of $\mathrm{RFI}_{\text {Lac100DIM }}$, we required that for each cow DMI and milk yield data begin by at least 23 DIM and there be at least $56 \mathrm{~d}$ of measurements to be included in the analysis. Given these criteria, the correlation between $\mathrm{RFI}_{\text {Lac100DIM }}$ and $\mathrm{RFI}_{\text {Lac-Full }}$ estimated from 10 to 305 DIM was only 0.72 , indicating that RFI estimated in early lactation does not provide a highly accurate estimate of whole-lactation RFI. Prendiville et al. (2011) reported similar findings where rank correlations of whole-lactation RFI versus RFI estimated before 60 DIM or between 61 and 120 DIM were poor $(r=0.47$ and 0.40 , respectively). Their study found correlations remained low $(\mathrm{r} \leq 0.52)$ even through mid-lactation, but increased to 0.71 for RFI estimated after 230 DIM. Among the periods examined, our combined analysis indicated that the magnitude of the correlation begins to decline in tests starting beyond 164 DIM, regardless of the test duration.

The poor correlation with $\mathrm{RFI}_{\text {Lac-Full }}$ particularly in early lactation is not surprising as previous research showed that partial regression coefficients of energy requirements for milk production and BW used to estimate energy intake and RFI are not stable across lactation (Li et al., 2017). That is, in early lactation cows often lose BW due to low feed intake relative to their high level of milk production, whereas cows in later stages of lactation generally gain BW. These changes in partial regression coefficients reflect inaccuracies in our ability to assess true changes in energy requirements for maintenance and body reserves change throughout the entire lactation period using indirect measures of ADG and metabolic BW. Results from this and our previous study (Connor et al., 2013) indicate selection for improved RFI during early lactation should reduce feed costs during this stage of production, but may not provide as great an improvement in whole-lactation feed efficiency as selection based on a test conducted near mid-lactation.

\section{Phenotypic Correlation of Heifer $\mathrm{RFI}_{\text {Growth }}$ to $R_{\text {Lac100DIM }}$}

The correlation between $\mathrm{RFI}_{\text {Growth }}$ and $\mathrm{RFI}_{\mathrm{Lac100DIM}}$ estimated from 130 heifers was statistically significant but relatively low $(\mathrm{r}=0.37)$ and indicated that only about $13 \%$ [i.e., $(0.37)^{2}$ ] of the variation in RFI during early lactation is explained by its relationship with RFI during growth in dairy cattle. It is relevant to note that among all 226 heifers evaluated for $\mathrm{RFI}_{\text {Growth }}, 30$ were among the 118 cows evaluated for $\mathrm{RFI}_{\text {Lac-Full, }}$ provid- 
ing some preliminary information on the relationships between $\mathrm{RFI}_{\text {Growth }}$ and $\mathrm{RFI}_{\text {Lac-Full }}$. Using all available animals to calculate RFI in both growth and lactation stages, the correlation of $\mathrm{RFI}_{\text {Growth }}$ versus $\mathrm{RFI}_{\text {Lac-Full }}$ remained significant $(\mathrm{r}=0.44 ; P<0.01 ;$ data not shown). Further investigation of the relationship between $\mathrm{RFI}_{\text {Growth }}$ and $\mathrm{RFI}_{\mathrm{Lac}-F u l l}$ is warranted.

Ranking of heifers as least ( $>0.5$ SD above mean), middle $( \pm 0.5 \mathrm{SD})$, or most efficient $(>0.5 \mathrm{SD}$ below mean) according to $\mathrm{RFI}_{\text {Growth }}$ resulted in only $43 \%$ maintaining the same ranking based on $\mathrm{RFI}_{\mathrm{Lac100DIM}}$ in the first lactation. Thus, estimates of RFI based on this classification are not highly repeatable within individual between these 2 dairy production phases of growth versus lactation. Delineation of efficiency groups by more extreme criteria (e.g., cut off $>1.0 \mathrm{SD}$ of mean RFI) could alter the percentage of animals maintaining the same efficiency ranking between growth and lactation stages. For comparison, Archer et al. (2002) calculated a correlation of 0.40 between $\mathrm{RFI}_{\text {Growth }}$ estimates in 7 - to 9-mo-old beef heifers versus as cows after their second calving, and Kelly et al. (2010) reported a correlation of 0.62 between RFI estimated in beef heifers during growth and finishing phases of production. In addition, Durunna et al. (2012) found that approximately $49 \%$ of growing crossbred beef heifers ranked consistently as high ( $>0.5$ SD above mean), medium $( \pm \mathrm{SD}$ of mean), or low ( $>0.5 \mathrm{SD}$ below mean) $\mathrm{RFI}_{\text {Growth }}$ groups during 2 consecutive test periods of approximately 8 wk each. The higher correlations reported between 2 phases of BW gain among beef cattle are not surprising compared with the correlation between 2 much more diverse physiological states of growth versus lactation among dairy cattle. Among all heifers evaluated for $\mathrm{RFI}_{\text {Growth, }} 30$ were among the 118 cows evaluated for $\mathrm{RFI}_{\text {Lac-Full }}$. Using all available data for both the growth and lactation stages, the correlation of $\mathrm{RFI}_{\text {Growth }}$ versus $\mathrm{RFI}_{\text {Lac-Full }}$ was 0.44 .

Furthermore, we found that observed divergence in $\mathrm{RFI}_{\text {Growth }}$ of $14 \%$ between the least and most efficient heifers (based on $\pm 0.5 \mathrm{SD}$ from the mean $\mathrm{RFI}_{\text {Growth }}$ ) was reduced to only $5 \%$ divergence in $\mathrm{RFI}_{\mathrm{Lac100DIM}}$. Similar to our results, growing dairy heifers in New Zealand and Australia with a $17 \%$ divergence in $\mathrm{RFI}_{\text {Growth }}$ (based on the top and bottom 10\% of their population) declined to just over $2 \%$ divergence in RFI during lactation (Macdonald et al., 2014). Recalculating divergence using only the top and bottom $10 \%$ of the population from our study (i.e., rather than $>0.5$ $\mathrm{SD}$ above or below the mean; $\mathrm{n}=13$ /group), equated to a divergence of $23 \%$ during growth and $10 \%$ during lactation. Macdonald et al. (2014) suggested the loss of divergence in RFI from the growth phase to lactation phase could, in part, be due to a smaller proportion of dietary energy being available to support maintenance during lactation relative to growth, thus creating a more limited opportunity for variation in metabolic efficiency (represented by RFI) among lactating cows. This reduction in divergence during lactation could also result from differences in the accuracy of our models to predict energy intake during the growth versus lactation phases of production.

Of interest, the most efficient heifers based on $\mathrm{RFI}_{\text {Growth }}$ maintained a $3.1 \%$ reduction in feed intake relative to the herd average during the first 100 DIM. This represents a savings of approximately $\$ 0.23$ / cow $\cdot \mathrm{d}^{-1}$ during the first 100 DIM using a May 2018 ration cost of $\$ 0.19 / \mathrm{kg}$ as fed (USDA-NASS, 2018). Actual cost savings will vary by how accurately RFI approximates true feed efficiency and the specific cost of the ration fed. Thus, in general, $\mathrm{RFI}_{\text {Growth }}$ may serve as an indicator trait for RFI during lactation, and selection for the most efficient heifers based on low $\mathrm{RFI}_{\text {Growth }}$ alone (e.g., no selection based on $\mathrm{RFI}_{\text {Lac100DIM }}$ ) may result in improved feed efficiency and lower feed costs during lactation. Indeed, additional research is needed in larger populations of dairy cattle to confirm this relationship.

\section{CONCLUSIONS}

Observed variations in $\mathrm{RFI}_{\text {Growth }}$ in heifers and $\mathrm{RFI}_{\text {Lac-Full }}$ in cows indicate opportunities to select for more feed-efficient dairy cows. Selection of the most efficient animals based on either estimate reduced feed intake at the corresponding production stage by approximately 6 to $8 \%$ relative to the herd average, with no apparent phenotypic changes in mean ECM, BW, or ADG. Estimation of RFI using a test period of 64 to $70 \mathrm{~d}$ in duration between approximately 150 to 220 DIM provided the best approximation of $\mathrm{RFI}_{\text {Lac-Full }}$ for the least time and effort among the periods tested. Lastly, selection for the most efficient heifers based on $\mathrm{RFI}_{\text {Growth }}$ should result in cows with lower RFI (greater feed efficiency) during early lactation, and $\mathrm{RFI}_{\text {Growth }}$ may be useful as an indicator trait for RFI among lactating cows.

\section{ACKNOWLEDGMENTS}

The authors acknowledge the excellent technical support of Mary Bowman, Donald Carbaugh, Christina Clover, Jonathan Leith, Mike Kemp, Charles Lowe, and Research Animal Services staff at the USDA Beltsville Agricultural Research Center. We also thank Kevin Garossino, David Benfield, and Camiel Huisma of GrowSafe Systems Ltd. and David Byers of Dairy Production Consultation (Galax, VA), who contributed 
to this project. Mention of trade names or commercial products in this article is solely for the purpose of providing specific information and does not imply recommendation or endorsement by the USDA. The USDA is an equal opportunity provider and employer.

\section{REFERENCES}

Archer, J. A., A. Reverter, R. M. Herd, D. J. Johnston, and P. F. Arthur. 2002. Genetic variation in feed intake and efficiency of mature beef cows and relationships with postweaning measurements. Page 10.07 in Proc. 7th World Congr. Genet. Appl. Livest. Prod. vol. 2002. Session 10.

Basarab, J. A., M. A. Price, J. L. Aalhus, E. K. Okine, W. M. Snelling, and K. L. Lyle. 2003. Residual feed intake and body composition in young growing cattle. Can. J. Anim. Sci. 83:189-204. https:// doi.org/10.4141/A02-065.

Berry, D. P., and J. J. Crowley. 2013. Cell Biology Symposium: Genetics of feed efficiency in dairy and beef cattle. J. Anim. Sci. 91:1594-1613. https://doi.org/10.2527/jas.2012-5862.

Carnie, K. R., S. R. Davis, K. A. Macdonald, G. C. Waghorn, V. V. Obolonkin, and R. J. Spelman. 2010. Variation in feed conversion efficiency in Holstein-Friesian heifer calves. Proc. N.Z. Soc. Anim. Prod. 70:250-252.

Connor, E. E. 2015. Invited review: Improving feed efficiency in dairy production: Challenges and possibilities. Animal 9:395-408. https: //doi.org/10.1017/S1751731114002997.

Connor, E. E., J. L. Hutchison, H. D. Norman, K. M. Olson, C. P. Van Tassell, J. M. Leith, and R. L. Baldwin. 2013. Use of residual feed intake in Holsteins during early lactation shows potential to improve feed efficiency through genetic selection. J. Anim. Sci. 91:3978-3988. https://doi.org/10.2527/jas.2012-5977.

Crowley, J. J., M. McGee, D. A. Kenny, D. H. Crews Jr., R. D. Evans, and D. P. Berry. 2010. Phenotypic and genetic parameters for different measures of feed efficiency in different breeds of Irish performance-tested beef bulls. J. Anim. Sci. 88:885-894. https:// doi.org/10.2527/jas.2009-1852.

Davis, S. R., K. A. Macdonald, G. C. Waghorn, and R. J. Spelman. 2014. Residual feed intake of lactating Holstein-Friesian cows predicted from high-density genotypes and phenotyping of growing heifers. J. Dairy Sci. 97:1436-1445. https://doi.org/10.3168/jds .2013-7205.

Durunna, O. N., M. G. Colazo, D. J. Ambrose, D. McCartney, V. S. Baron, and J. A. Basarab. 2012. Evidence of residual feed intake reranking in crossbred replacement heifers. J. Anim. Sci. 90:734741. https://doi.org/10.2527/jas.2011-4264.

Fischer, A., N. C. Friggens, D. P. Berry, and P. Faverdin. 2018. Isolating the cow-specific part of residual energy intake in lactating cows using random regressions. Animal 12:1396-1404. https://doi.org/ $10.1017 /$ S1751731117003214.

Gonzalez-Recio, O., J. E. Pryce, M. Haile-Mariam, and B. J. Hayes. 2014. Incorporating heifer feed efficiency in the Australian selection index using genomic selection. J. Dairy Sci. 97:3883-3893. https://doi.org/10.3168/jds.2013-7515.

Heinrichs, J., P. Tozer, M. Gabler, and T. Schriefer. 2016. Heifer economics. Accessed Jul. 12, 2018. https://extension.psu.edu/heifer -economics.

Hurley, A. M., N. Lopez-Villalobos, S. McParland, E. Lewis, E. Kennedy, M. O'Donovan, and J. L. Burke. 2018. Characteristics of feed efficiency within and across lactation in dairy cows and the effect of genetic selection. J. Dairy Sci. 101:1267-1280. https://doi.org/ $10.3168 /$ jds.2017-12841.

Kelly, A. K., M. McGee, D. H. Crews, T. Sweeney, T. M. Boland, and D. A. Kenny. 2010. Repeatability of feed efficiency, carcass ultrasound, feeding behavior, and blood metabolic variables in finishing heifers divergently selected for residual feed intake. J. Anim. Sci. 88:3214-3225. https://doi.org/10.2527/jas.2009-2700.

Koch, R. M., L. A. Swiger, D. Chambers, and K. E. Gregory. 1963. Efficiency of feed use in beef cattle. J. Anim. Sci. 22:486-494.
Korver, S., E. A. van Eekelen, H. Vos, G. Nieuwhof, and J. A. van Arendonk. 1991. Genetic parameters for feed intake and feed efficiency in growing dairy heifers. Livest. Prod. Sci. 29:49-59. https: //doi.org/10.1016/0301-6226(91)90119-B.

Lancaster, P. A., G. E. Carstens, D. H. Crews Jr., T. H. Welsh Jr., T. D. A. Forbes, D. W. Forrest, L. O. Tedeschi, R. D. Randel, and F. M. Rouquette. 2009. Phenotypic and genetic relationships of residual feed intake with performance and ultrasound carcass traits in Brangus heifers. J. Anim. Sci. 87:3887-3896. https://doi.org/10 $.2527 /$ jas.2009-2041.

Li, B., B. Berglund, W. F. Fikse, J. Lassen, M. H. Lidauer, P. Mäntysaari, and P. Løvendahl. 2017. Neglect of lactation stage leads to naive assessment of residual feed intake in dairy cattle. J. Dairy Sci. 100:9076-9084. https://doi.org/10.3168/jds.2017-12775.

Løvendahl, P., G. F. Difford, B. Li, M. G. G. Chagunda, P. Huhtanen, M. H. Lidauer, J. Lassen, and P. Lund. 2018. Review: Selecting for improved feed efficiency and reduced methane emissions in dairy cattle. Animal Sep 26:1-14. https://doi.org/10.1017/ S1751731118002276.

Macdonald, K. A.. J. E. Pryce, R. J. Spelman, S. R. Davis, W. J. Wales, G. C. Waghorn, Y. J. Williams, L. C. Marett, and B. J. Hayes. 2014. Holstein-Friesian calves selected for divergence in residual feed intake during growth exhibited significant but reduced residual feed intake divergence in their first lactation. J. Dairy Sci. 97:1427-1435. https://doi.org/10.3168/jds.2013-7227.

Manafiazar, G., T. McFadden, L. Goonewardene, E. Okine, J. Basarab, P. Li, and Z. Wang. 2013. Prediction of residual feed intake for first-lactation dairy cows using orthogonal polynomial random regression. J. Dairy Sci. 96:7991-8001. https://doi.org/10.3168/ jds.2013-6560.

Mäntysaari, P., A.-E. Liinamo, and E. A. Mäntysaari. 2012. Energy efficiency and its relationship with milk, body, and intake traits and energy status among primiparous Nordic Red dairy cattle. J. Dairy Sci. 95:3200-3211. https://doi.org/10.3168/jds.2011-4685.

National Research Council. 2001. Nutrient Requirements of Dairy Cattle. 7th rev. ed. Natl. Acad. Press, Washington, DC. https:// doi.org/10.17226/9825.

Ngwerume, F., and I. L. Mao. 1992. Estimation of residual energy intake for lactating cows using an animal model. J. Dairy Sci. 75:2283-2287. https://doi.org/10.3168/jds.S0022-0302(92)77989 -2 .

Orth, R. 1992. Sample day and lactation report. DHIA 200 Fact Sheet A-2. Mid-states DRPC, Ames, IA.

Prendiville, R., K. M. Pierce, L. Delaby, and F. Buckley. 2011. Animal performance and production efficiencies of Holstein-Friesian, Jersey and Jersey $\times$ Holstein-Friesian cows throughout lactation. Livest. Sci. 138:25-33. https://doi.org/10.1016/j.livsci.2010.11.023.

Pryce, J. E., W. J. Wales, Y. de Haas, R. F. Veerkamp, and B. J. Hayes. 2014. Genomic selection for feed efficiency in dairy cattle. Animal 8:1-10. https://doi.org/10.1017/S1751731113001687.

US Department of Agriculture-Economic Research Service. 2018. Milk cost of production estimates. Accessed Feb. 13, 2018. http://www .ers.usda.gov/data-products/milk-cost-of-production-estimates/.

US Department of Agriculture- National Agricultural Statistics Service. 2018. Agricultural Prices June 28, 2018. Accessed Jul. 12, 2018. http://usda.mannlib.cornell.edu/MannUsda/viewDocumentInfo .do?documentID $=1002$.

Van Arendonk, J. A. M., G. J. Nieuwhof, H. Vos, and S. Korver. 1991. Genetic aspects of feed intake and efficiency in lactating dairy heifers. Livest. Prod. Sci. 29:263-275.

VandeHaar, M. J., L. E. Armentano, K. Weigel, D. M. Spurlock, R. J. Tempelman, and R. Veerkamp. 2016. Harnessing the genetics of the modern dairy cow to continue improvements in feed efficiency. J. Dairy Sci. 99:4941-4954. https://doi.org/10.3168/jds .2015-10352.

Williams, Y. J., J. E. Pryce, C. Grainger, W. J. Wales, N. Linden, M. Porker, and B. J. Hayes. 2011. Variation in residual feed intake in Holstein-Friesian dairy heifers in southern Australia. J. Dairy Sci. 94:4715-4725. https://doi.org/10.3168/jds.2010-4015. 